\title{
DAMPAK PELAKSANAAN SISTEM PEMERINTAHAN FEODALISME TERHADAP PEMBENTUKAN SISTEM STRATIFIKASI SOSIAL (SHINOKOSHO) PADA ZAMAN EDO
}

\author{
Sri Dewi Andriani \\ Jurusan Sastra Jepang, Fakultas Humaniora, BINUS University \\ Jln. Kemangisan Ilir III No. 45, Kemanggisan, Palmerah, Jakarta Barat 11480
}

\begin{abstract}
Tokugawa governance is military rezime government in Japan during 17th to 19th century. The governance was led by a general or known as shogun helped by daimyo or the head of district governance or han. Shogun was held hereditary by Tokugawa family. Japan military governance applied tightened inspection for the people to maintain the power. One of well-known stratification community social system is shinokosho, which divided people into four social classes: military, farmer, trader, and artisan. The research will discuss problems in the effects of feodalism governance system towards the formation of social stratification system shinokosho. The research methods used are descriptive, analitic and qualitative. The result is that the application in this tightened system made people could not change status that finally made Tokugawa family hereditary could have the governance power for more than 250 years.
\end{abstract}

Keywords: shogun, daimyo, han, shinokosho, feodalism

\begin{abstract}
ABSTRAK
Pemerintahan Tokugawa adalah pemerintahan oleh rezim militer di Jepang yang pernah berlangsung pada abad 17 sampai 19. Pemerintahan ini dikepalai oleh seorang jenderal atau yang dikenal dengan shogun dan dibantu oleh daimyo atau kepala pemerintahan di daerah atau han. Shogun dipegang secara turun-temurun oleh keluarga Tokugawa. Pemerintahan militer Jepang menerapkan sistem pengawasan yang ketat pada rakyatnya demi mempertahankan kekuasaannya. Salah satu penerapan sistem stratifikasi sosial masyarakat yang dikenal adalah shinokosho, yang membagi masyarakat dalam empat kelas sosial yaitu militer, petani, pedagang dan pengrajin. Penelitian ini akan membahas permasalahan mengenai dampak sistem pemerintahan feodalisme terhadap pembentukan sistem stratifikasi sosial Shinokosho. Tujuannya adalah untuk mengetahui dampak pembentukan sistem pemerintahan feodalisme terhadap pembentukan sistem stratifikasi sosial Shinokosho. Metode penelitian yang digunakan adalah deskriptif, analitis dan kualitatif. Hasil kesimpulan yang didapat adalah bahwa penerapan sistem ini secara ketat membuat masyarakat tidak dapat beganti status yang akhirnya membuat keturunan keluarga Tokugawa dapat melenggang bebas berkuasa selama kurun waktu lebih dari 250 tahun.
\end{abstract}

Kata kunci: Shogun, daimyo, han, shinokosho, feodalisme 


\section{PENDAHULUAN}

Zaman Edo (1868 1912) adalah suatu masa dimana Jepang berada di bawah kekuasaan suatu pemerintahan kelas atau kelompok militer. Pemerintahan oleh kelompok militer dikenal dengan nama Bakufu, sedangkan kelompok militer tersebut dinamai kaum Bushi atau samurai. Tenno atau kaisar diisolasi dari segala kegiatan politik dan pemerintahan. Ia hanya diperkenankan melaksanakan kegiatan yang berhubungan dengan lembaga kekaisaran seperti penganugerahan tanda jasa dan gelargelar kehormatan (Totman, 1967). Pemerintahan dijalankan oleh seorang Shogun atau jenderal militer yang bertindak sebagai kepala pemerintahan pusat.

Sebagai pemimpin pemerintahan di daerah, shogun menunjuk Daimyo yang dibantu oleh para pembantu dekatnya seperti Hatamoto dan Gokenin. Jumlah daimyo pada saat itu berkisar 260 270 orang dan masing-masing daimyo diberikan tanah yang luasnya antara 10.000 sampai 1 juta koku beras (1 koku =172,8 liter beras). Tanah-tanah inilah yang di sebut dengan Han atau Kedaimyoan (Dore, 1965).

Sebagai shogun pertama ditunjuklah Tokugawa Ieyasu. Ia adalah putera seorang prajurit bernama Hirodata yang merupakan keturunan keluarga Matsudaira. Keluarga Matsudaira sendiri adalah salah satu keluarga yang berkuasa di propinsi Mikawa. Selama masa kepemimpinannya ia berhasil membentuk suatu organisasi kepemimpinan yang sederhana namun ketat terutama dalam hal pengawasan atas perkembangan para prajuritnya. Ia menempatkan prajurit atau pengikutnya sesuai dengan tingkat kesetiaan mereka demi menghindari timbulnya pemberontakan. Ieyasu juga menciptakan pembagian hirarki yang didasarkan atas bidang pekerjaan masing-masing. Ieyasu tumbuh menjadi salah seorang daimyo terkuat dengan wilayah kekuasaan yang meliputi Kanto, Chubu dan Osaka. Pada perkembangan selanjutnya ia berhasil merebut kekuasaan yang ditinggalkan akibat meninggalnya pemimpin sebelumnya, Toyotomi Hideyoshi. Peristwa perebutan kekuasaan ini ditandai dengan meletusnya pertempuran yang dikenal dengan perang Sekigara. Setelah mengalami kesuksesan dalam pertempuran tersebut, Ieyasu mendirikan pemerintahannya yang berpusat di Edo. Masa pemerintahan oleh rezim militer ini berlangsung dari tahun 1603-1867. Pemerintahan pada masa itu dipegang oleh keluarga Tokugawa secara turun temurun oleh karena itu zaman Edo juga sering disebut dengan zaman Tokugawa.

Penelitian ini akan membahas permasalahan mengenai dampak sistem pemerintahan feodalisme terhadap pembentukan sistem stratifikasi sosial Shinokosho. Sementara itu, tujuan dari penelitian ini adalah adalah untuk mengetahui dampak pembentukan sistem sistem pemerintahan feodalisme terhadap pembentukan sistem stratifikasi sosial Shinokosho.

\section{METODE}

Metode penelitian yang digunakan adalah deskriptif, analitif dan kualitatif yaitu dengan menpa buku, data statistik serta bahan lain yang relevan dengan penlitian. Data penelitian yang telah dikumpulkan kemudain dianalisis dengan menggunakan pendekatan kualitatif dengan perspektif historis yaitu dengan melakukan analis secara objektif terhadap permasalahan atas dasar data-data sejarah.

Harapan akan hasil penelitian ini adalah agar pembaca mendapat pemahaman mengenai dampak pembentukan sistem pemerintahan feodalisme terhadap politik diskriminasi sosial di Jepang pada zaman Edo. 


\section{PEMBAHASAN}

\section{Pemerintahan Feodalisme Zaman Edo}

Dalam rangka pelaksanaan pemerintahan, dibuatlah suatu sistem pengawasan yang bersifat hirarkis dan masal dalam kalangan militer. Pada puncaknya duduklah pemimpin asal Tokugawa yaitu shogun yang sedang memerintah. Orang-orang yang langsung berada di bawahnya ialah Kashin (para pembantu langsungnya). Pangkat mereka mulai dari jajaran yang penting sampai yang kurang penting yaitu Daimyo, Hatamoto, Gokenin dan Koke. Mereka semua berada di bawah pengawasan pejabat bakufu, baik dalam keadaan perang maupun tidak. Karena itulah hubungan mereka terhadap atasannya dikenal sebagai Shihai teki Shujusei atau sistem hubungan pengawasan atasan-bawahan (Ishii, 1988). Kashin menyampaikan perintah-perintah bakufu kepada bawahan mereka dan meneruskan permintaan dari para bawahannya itu kepada pemimpin bakufu tersebut. Mekanisme pemerintahan semi otonomi di mana shogun melimpahkan wewenang dan kekuasaan kepada daimyo di daerah, di kenal dengan sistem Bakuhan atau Bakuhan Taisei.

Di dalam sistem ini bakufu juga bertugas mengawasi tanah yang luasnya seperempat luas tanah seluruh Jepang atau kira-kira suatu jumlah luas tanah yang menghasilkan 4,2 juta koku beras pertahun. Tanah-tanah ini dikontrol langsung oleh Kanjo Bugyo (pengawas tanah dan keuangan) dengan bantuan Gundai/Daikan (pembantu Kanjo Bugyo). Tanah-tanah ini disebut Tenryo atau tanah milik penguasa bakufu yang terletak antara lain di Kyoto, Osaka, Nagasaki dan Sado. Di sana bakufu melaksanakan perdagangan dan sistem keuangan secara monopoli.

Pada akhir zaman Edo jumlah seluruh tanah yang telah dinilai pajaknya berjumlah kurang lebih 30 juta koku. Walaupun demikian bakufu hanya menguasai secara langsung sebanyak 7 juta koku beras, dan dari jumlah itu sebanyak 2,6 atau 2,7 koku telah dihadiahkan sebagai bantuan kepada para pembantu langsungnya yaitu Hatamoto atau Gokenin. Kebanyakan tanah yang tersisa di Jepang yang menghasilkan 22 atau 23 juta koku diperuntukan bagi daimyo yang memiliki pengikut lebih dari 70 ribu (Totman, 1967). Para daimyo ini secara resmi dibebani tugas mengatur wilayah-wilayah kekuasaan mereka.

Para daimyo diikat oleh berbagai peraturan di antaranya adalah peraturan yang memuat tentang prilaku kemiliteran yang disebut dengan Buke Sho-Hatto. Peraturan ini dicetuskan oleh Tokugawa Ieyasu dan dikeluarkan pada tahun 1615. Dalam Passin (1967)163-166, peraturan yang disebut dengan Buke Shohatto itu berbunyi seperti di bawah ini.

1. Keahlian untuk damai dan perang termasuk memanah dan berkuda harus dilaksanakan dengan sungguh-sungguh, kalimat ini bersumber dari pepatah kuno yang berbunyi keahlian untuk damai di tangan kiri, dan keahlian untuk perang di tangan kanan. Keduanya harus dikuasai. Memanah dan berkuda sangat dibutuhkan oleh kaum militer. Akan tetapi meskipun senjata disebut sebagai alat kejahatan tetapi pada waktu tertentu alat tersebut harus digunakan;

2. Minum dan pesta pora harus dihindarkan, dalam peraturan yang diberikan prostitusi dan berjudi termasuk dilarang keras karena dapat meruntuhkan negara;

3. Pelanggar peraturan tidak boleh dilindungi atau disembunyikan di daerah (Han) manapun;

4. Daimyo, bangsawan dan petugas negara harus segera mengusir siapapun diantara pengikutnya yang didakwa mengkhianat atau membunuh dari daerahnya. Penghianat atau pembunuh dapat menjadi senjata untuk mengalahkan negara dan membunuh masyarakatnya. Orang semacam itu tidak bisa dibiarkan bebas;

5. Tidak ada orang asing yang diperbolehkan tinggal dalam han kecuali penduduk daerah tersebut. Setiap daerah memiliki cara pemerintahan masing-masing. Jika seorang membocorkan rahasia daerahnya kepada daerah lain atau sebaliknya maka hal ini akan menimbulkan kebiasaan 
berbohong dan mencari keuntungan sendiri. Jika bermaksud mengadakan perbaikan atas puri dari salah satu daerah Han, harus memberitahu kepada penguasa;

6. Laporan harus segera dibuat jika ditemukan rencana pembaruan atau pembentukan kelompok rahasia di daerah tetangga;

7. Jangan menikah tanpa memberitahukan penguasa bakufu;

8. Kunjungan daimyo ke ibukota harus mematuhi ketentuan. Di dalam hal kunjungan ini ada aturan lain yang harus diikuti meliputi jumlah pengawal yang menyertainya. Jumlahnya tergantung dari jumlah beras yang dihasilkan oleh daerahnya masing-masing;

9. Peraturan tentang jenis dan kualitas pakaian yang digunakan tidak boleh dilanggar;

10. Hanya orang tertentu yang boleh naik tandu. Yang diperbolehkan ikut naik tandu hanyalah bangsawan dari beberapa daerah, relasi dan pejabat pemerintahan, dokter dan ahli astronomi, mereka yang berusia diatas 60 tahun dan orang sakit;

11. Samurai dari daerah-daerah harus hidup sederhana dan hemat;

12. Daimyo harus memilih pejabat daerah yang mampu mengatur massa; dan

13. Daimyo harus memilih pejabat daerah yang mampu mengatur massa (pp. 163-166)

Kemudian secara bergiliran dalam waktu satu tahun mereka harus bermukim di Edo dan di han-nya bersama anak dan isterinya yang dikenal dengan peraturan Sankin Kotai. Peraturan ini sebenarnya dimaksudkan agar bakufu lebih mudah mengontrol para daimyo. Dengan adanya peraturan ini daimyo tidak mempunyai kesempatan menghimpun kekuatan di daerah untuk menggulingkan pemerintahan pusat. Diterapkannya sistem Sankin Kotai ini di satu sisi memiliki dampak yang buruk terhadap perekonomian han sebab selama melaksanakan perjalanannya, daimyo beserta rombongan banyak menghabiskan biaya sehingga keuangan han menjadi terganggu. Akan tetapi di sisi lain peraturan itu berdampak positif karena menggairahkan perdagangan khususnya di kota-kota yang dilalui oleh rombongan.

Segi status daimyo ini begitu penting bagi bakufu sehingga pemerintahan yang kurang baik serta penyalahgunaan kekuasaan oleh daimyo mengakibatkan hukuman yang sama dengan pemberontakan dan pelanggaran sumpah setia. Dalam kasus semacam itu, seorang daimyo dapat mengalami pengurangan luas han yang diperolehnya, dipaksa pindah dari tanahnya ke tanah lain atau pembubaran keluarganya sebagai unsur penguasa.

Para daimyo dibagi atas tiga golongan yaitu Shinpan Daimyo yang merupakan keturunan langsung Tokugawa, Fudai Daimyo yaitu pengikut Ieyasu sewaktu berkuasa di Mikawa dan Tozama Daimyo yang diangkat oleh Ieyasu setelah perang Sekigahara (Ishii, 1988). Penempatan daimyo juga ditentukan atas dasar kesetiannya pada bakufu. Daimyo yang paling setia di tempatkan di sekitar Edo dan yang diragukan kesetiannya ditempatkan di wilayah yang jauh dari Edo.

Dalam rangka pelaksanaan pemerintahan serta interaksi sosial masyarakat, pemerintah menetapkan ajaran konfusianisme aliran Chu shi atau Shushigaku sebagai dasar pemikiran dalam hubungan sosial tersebut. Aliran ini dipilih karena ajarannya dirasakan dapat mendukung keberadaan kelas militer sebagai penguasa pada saat itu serta kestabilan pelaksanaan stratifikasi sosial masyarakat atau yang dikenal dengan Shinokosho. Dasar-dasar pemikiran konfusianisme aliran Chu Shi ini disamping menjadi suatu dasar pemikiran dalam hubungan sosial masyarakat secara umum, juga dijadikan pedoman dalam interaksi antara anggota Ie sebagai suatu bentuk keluarga tradisional Jepang.

\section{Pelaksanaan Sistem Stratifikasi Sosial (Shinokosho)}

Suatu unsur lain yang sangat penting dalam memelihara sistem feodal ini dengan mantap adalah adanya kestabilan kelas. Demi terpeliharanya kedudukan istimewa kaum militer, maka pemerintah Edo menganut sistem pembedaan kelas yang sangat ketat dikenal dengan Shinokosho yang terdiri atas kelas Bushi (militer), Nomin (petani), Kosakunin(pengerajin), Shonin (pedagang) serta 
kelas yang terendah yaitu Eta atau Hinin (kaum budak). Sistem pembedaan kelas ini mula-mula dicetuskan oleh Toyotomi Hideyoshi yang membagi masyarakat menjadi dua kelas masing-masing kelas samurai dan petani. Kebijaksanaan ini dikenal sebagai Heino Bunri.

Sistem pembedaan kelas ini mengatur dengan ketat status dan peran dari masing-masing kelas serta berlaku turun temurun. Untuk menjaga kestabilannya, sistem Ie sebagai adat kebiasaan yang ada dalam masyarakat dijalankan dengan ketat khususnya dalam masyarakat samurai. Di dalam sistem ini seseorang tidak diperbolehkan menukar status kelasnya, tidak bisa naik ke kelas yang lebih tinggi atau mengubah statusnya serta dilarang mengadakan pernikahan dengan yang berlainan kelas. Sistem pembedaan kelas merupakan upaya yang dilakukan oleh pemerintah militer untuk mempertahankan kekuasaannya.

Kelas militer adalah kelas yang mendapatkan kedudukan yang paling tinggi meskipun prosentasenya hanya mencapai $10 \%$ dari keseluruhan masyarakat saat itu. Hal ini disebabkan karena kelas militer adalah pemegang kekuasaan politik dan pemerintahan. Kelompok yang termasuk dalam golongan ini adalah semua anggota keluarga militer mulai dari panglima perang sampai samurai rendahan. Interaksi diantara mereka didasarkan atas kedudukannya dalam pemerintahan. Untuk mengatur prilaku kaum Bushi tersebut, pemerintah mendeklarasikan peraturan yang mengatur segala gerak-gerik mereka. Peraturan yang disebut dengan Buke Shohatto ini merupakan ringkasan dari peraturan dan peringatan yang isinya yaitu bahwa di bawah kelas militer terdapat kelas-kelas lain yang kedudukannya ditentukan oleh produktifitas mereka. Petani berada pada tingkat teratas setelah militer karena menjadi sumber penghasilan utama dari penguasa. Petani merupakan kelompok yang menghasilkan barang-barang kebutuhan pokok yang dibutuhkan masyarakat. Sebagai negara yang berlandaskan ekonomi pertanian, petani merupakan elemen yang paling penting dan memiliki populasi terbanyak yaitu mencapai $80 \%$ dari total keseluruhan masyarakat. Akan tetapi kehidupan petani sangatlah berat akibat beban pajak yang tinggi. Ada dua macam petani yaitu Honbyakusho (petani pemilik tanah) dan Mizuno Miyakusho (petani penggarap). Gambar 1 adalah grafik yang memperlihatkan prosentase masyarakat yang terbagi dalam lima kelas sosial. Dalam grafik ini terlihat bahwa kaum petani adalah kelompok yang menjadi mayoritas dalam struktur masyarakat Jepang saat itu.

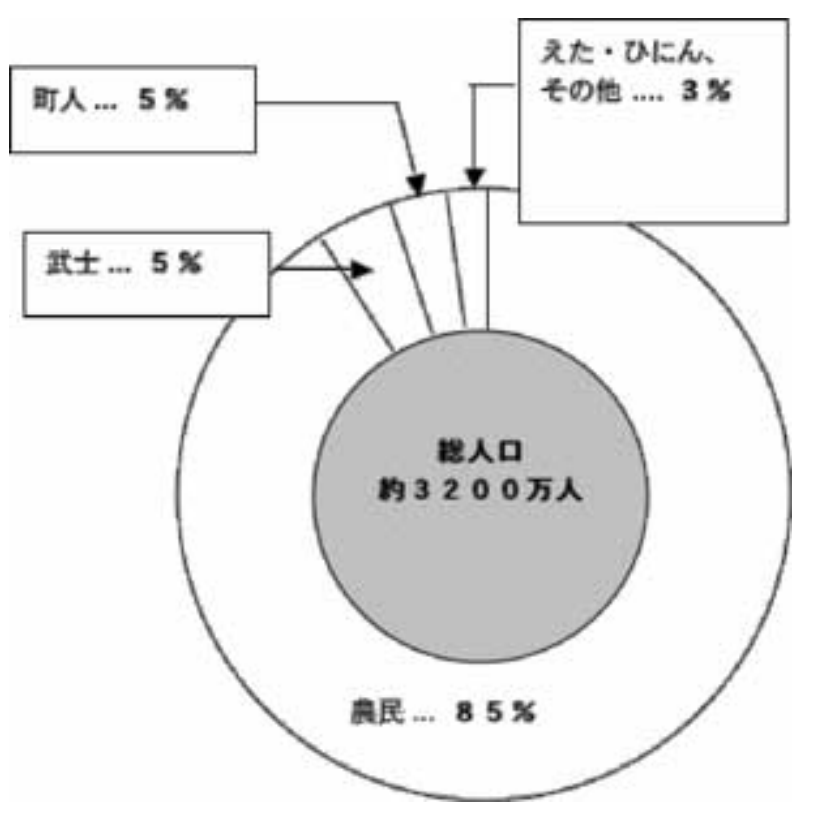

Gambar 1 Grafik prosentasi masyarakat Jepang Sumber: Japanese Mosaic (n.d.) 
Sebagai kelas produktif lainnya pengrajin menduduki kelas dibawah petani karena pengrajin meskipun tidak menghasilkan barang-barang kebutuhan pokok namun mereka memiliki pengetahuan dan kecakapan khusus yang dihargai terutama yang menghasilkan kebutuhan untuk kelas militer. Seperti halnya petani, kelompok pengerajin juga terbagi ada dua bagian yaitu Goyo Shokunin atau pengerajin terhormat (pengerajin yang mendapat pesanan dari bakufu) serta Hira Shokunin atau pengerajin biasa (pengerajin yang pesanannya bukan berasal dari bakufu).

Pedagang berada pada urutan terbawah dalam sistem ini. Pedagang mendapatkan status terendah dalam masyarakat karena dianggap sebagai kelas yang tidak produkti. Pedagang dianggap sebagai pekerjaan yang rendah karena hanya mengambil keuntungan dari hasil kerja orang lain. Meskipun di dalam sistem stratifikasi sosial menduduki urutan terbawah namun dari segi finansial kaum pedagang memiliki kesempatan untuk menumpuk kekayaan.

Di luar sistem Shinokosho ini ada pula kelompok masyarakat yang digolongkan sebagai kelompok Eta dan Hinin. Kelompok ini disebut juga Burakumin. Dalam kehidupan sosialnya mereka memperoleh status yang sangat rendah serta dilarang untuk bertani. Kemajuan di bidang perdagangan yang telah memberikan banyak keuntungan bagi pemerintahan menimbulkan persoalan bagi kestabilan Shi-No-Ko-Sho tersebut.

Dampak yang diakibatkan oleh meningkatnya perdagangan ini adalah semakin meluasnya penyebaran agama kristen di Jepang. Pada tahun 1605 penganut agama kristen sudah mencapai 700.000 orang. Hal ini tentu saja sangat mengkhawatirkan pemerintah karena ajaran kristen yang menekankan kesetaraan derajat manusia di hadapan Tuhan sangatlah bertentangan dengan prinsip ShiNo-Ko-Sho. Sejak saat itu mulailah tekanan-tekanan terhadap agama kristen dijalankan. Diawali dengan shogun ketiga Iemitsu yang mengeluarkan larangan bagi orang Spanyol untuk masuk ke Jepang serta orang Jepang ke luar negeri. Selain itu ia juga memanggil orang Jepang di luar negeri untuk kembali ke Jepang. Pada tahun 1639 kapal Portugis dilarang masuk ke Jepang dan tahun 1641 kantor dagang Belanda di Hirado dipindahkan ke pulau Dejima di Nagasaki. Sehingga Nagasaki menjadi satu satunya pintu masuk bagi perdagangan luar negeri serta hanya Belanda dan Cina saja yang diizinkan masuk. Hal ini menandai Sakoku Seisaku atau politik penutupan negara. Politik ini membantu memperkuat dan mengamankan pengendalian bakufu atas seluruh negara serta mendorong perkembangan kebudayaan tradisonal Jepang.

Akan tetapi pada masa pemerintahan Shogun ke empat, Ietsuna, tekanan-tekanan itu mulai diperlonggar. Ietsuna lebih menekankan politik pemerintahannya pada bidang pendidikan dan kebudayaan. Hal ini disebabkan karena keadaan Jepang yang dirasakan sudah mulai aman serta tindakan-tindakan penekanan terhadap daimyo sudah tidak dianggap perlu lagi. Terlebih pada masa pemerintahan Shogun Tsunayoshi, perdamaian dan kemakmuran telah dicapai sehingga zaman ini disebut zaman Genroku (1688 1704). Kota-kota berkembang dengan pesat. Industri, perhubungan, distribusi barang dan perdagangan maju dengan baik. Dengan dasar kemakmuran ekonomi ini ilmu pengetahuan kesusastraan dan kesenian maju dengan pesat.

\section{Dampak Pelaksanaan Sistem Shinokosho}

Pembentukan sistem shinokosho merupakan strategi dari pemerintahan feodal edo untuk mempertahankan supremasi pemerintahan di tangan keluarga Tokugawa. Masyarakat diawasi secara ketat dengan cara mengelompokkan mereka dalam kelas kelas sosial tertentu. Status yang dilekatkan kepada mereka berlaku tetap sejak lahir hingga mati. Hal ini membuat siapa pun orang tidak dapat mengganti status sosialnya atau meningkatkan statusnya ke level yang lebih tinggi.

Kaum petani menduduki prosentase terbanyak dalam struktur masyarakat Jepang saat itu, diikuti oleh kaum militer, pedagang, pengerajin dan kaum budak. Adanya aturan ketat yang membatasi 
adanya perpindahan dari satu kelas ke kelas lain, membuat kekuasaan yang berada di tangan keluarga Tokugawa dapat dipertahankan secara turun temurun selama lebih dari 250 tahun.

Pada pelaksanaannya para samurai yang tergolong dalam kelas sosial teratas juga dibagi lagi berdasarkan kedekatannya dengan pemerintah pusat. Hal ini menunjukkan masih adanya kekhawatiran di kalangan pemerintah pusat akan kemungkinan para samurai akan berkhianat. Berbagai aturan dan kebijakan diterapkan kepada kaun samurai yang intinya bermuara pada pengawasan terhadap mereka. Peraturan itu diantaranya adalah sankin kotai dan buke shohatto. Segala bentuk ajaran yang dapat mengoyahkan kekuasaan keluarga ini akan ditumpas habis. Salah satunya adalah melarang perkembangan ajaran kristen yang ajarannya dianggap bertentangan dengan ideologi pemerintah saat itu. Kebijakan lain yang diberlakukan adalah penerapan sakoku atau politik penutupan negeri yang membatasi orang asing maupun unsur budayanya untuk masuk ke Jepang maupun orang Jepang ke luar dari Jepang.

\section{PENUTUP}

Sistem stratifikasi sosial masyarakat di zaman edo (shinokosho) yang diberlakukan oleh pemerintah saat itu telah berhasil dijadikan sebagai salah satu alat politik untuk mempertahankan supremasi kekuasaan mererka. Penerapan sistem ini secara ketat membuat masyarakat tidak dapat beganti status yang akhirnya membuat keturunan keluarga Tokugawa dapat melenggang bebas berkuasa selama kurun waktu lebih dari 250 tahun. Kebijakan ini bukan satu satunya kebijakan yang dikeluarkan, namun masih ada beberapa peraturan lain. Peraturan tersebut antara lain adalah pelarangan masuknya ajaran agama kristen, politik penutupan negeri (sakoku), sankin kotai dan berbagai peraturan lainnya.

\section{DAFTAR PUSTAKA}

Dore, R. P. (1984). Education in Tokugawa Japan. London: The Athlone Press.

Fukutake, T. (1989). Masyarakat pedesaan di Jepang. (Haryono, terj.). Jakarta: Gramedia Pustaka Utama.

Ishii, R. (1989). Sejarah institusi politik Jepang. Jakarta: Gramedia Pustaka Utama.

Japanese Mosaic. (n.d.). Social hierarcy system. Diakses dari The Center for Applied Second Language Studies: http://casls.uoregon.edu/mosaic/JP_mosaic/tokaido/U2/A7/JP-4023.html

Passin, H. (1976). Society and education in Japan. Colombia: Teachers College Press.

Totman, C. D. (1967). Politic in the Tokugawa Bakufu, 1603-1843. Cambridge, Massachusetts: Harvard University Press. 